\title{
COMMENT
}

\section{An Unexpected Breakthrough in Hong Kong's Constitutional Reform}

\section{Albert H. Y. Chen"}

In a previous comment published in this Journal, ${ }^{1}$ I have introduced readers to the Hong Kong Special Administrative Region (HKSAR) Government's Consultation Document on Methods for Selecting the Chief Executive and for Forming the Legislative Council in 2012 published on 18 November 2009. The present comment updates readers on developments since then, particularly the unexpected turn of events in the week of 14-20 June 2010 which led to the Government's constitutional reform proposals being passed by the Legislative Council (LegCo) of the HKSAR on 24 and 25 June 2010.2

As mentioned in my previous comment, the "pan-democrats" (including the Democratic Party (DP), the Civic Party (CP), the League of Social Democrats (LSD), the Association for Democracy and People's Livelihood (ADPL) and their allies, which occupied 23 seats in the 60-seat LegCo) - who had the power to veto any constitutional reform package in the form of amendments to Annexes I and II to the Basic Law which require a two-thirds majority in LegCo - were opposed to the proposal in the Consultation Document. Nevertheless, after considering the views of members of the public collected during the three-month consultation period for the Consultation Document, the Government on 14 April 2010 formally announced its Package of Proposals for the Methods for Selecting the Chief Executive and for Forming the Legislative Council in $2012^{3}$ - a constitutional reform proposal ("the Reform Package") that is basically the same as that proposed in the Consultation Document. The motions for the relevant amendments to Annexes I and II of the Basic Law for the purpose of implementing the Reform Package were formally submitted to LegCo on 7 June 2010 for debate and voting on 23 June 2010.

The reasons for the pan-democrats' opposition to the Reform Package have been documented in my previous comment. It is noteworthy, however, that as from autumn 2009, the pan-democrats became split

Chan, Professor in Constitutional Law, Faculty of Law, University of Hong Kong.

Albert H. Y. Chen, "Constitutional Developments in Autumn 2009” (2009) 39 HKLJ 751.

The facts mentioned in this comment have been reported in Hong Kong newspapers; footnote references will not be supplied here except where strictly necessary.

3 See www.cmab-cd2012.gov.hk. 
into two camps (the "moderate" and "radical" camps) which adopted different approaches or strategies in their struggle for democratisation in the HKSAR. The "radical" camp, consisting of the CP and LSD, engaged in the "referendum" campaign to gather mass support for democratisation and the abolition of functional constituencies. ${ }^{4}$ The "moderate" camp, led by the DP which cooperated with some prodemocracy groups, politicians and scholars in forming the Alliance for Universal Suffrage, ${ }^{5}$ sought to work out concrete demands and proposals and negotiate with the HKSAR Government and Beijing. ${ }^{6}$

Despite a statement from the Hong Kong and Macau Affairs Office of the State Council in Beijing that the "referendum" advocated by the CP and LSD would be inconsistent with Hong Kong's constitutional status and contrary to the Basic Law, the CP and LSD on 21 January 2010 formally launched the campaign of five of their LegCo members resigning so as to trigger what they promoted as a de facto referendum in each of the five geographical constituencies for LegCo elections in the HKSAR on the introduction of genuine universal suffrage (for the election of the Chief Executive and all legislators) and abolition of functional constituencies for LegCo elections. The resignations were tendered in the following week, and the by-election to fill the resulting vacancies in LegCo was held on 16 May 2010. The pro-Government political parties and groups boycotted the election, although some candidates with no backing from major political parties and groups participated in it. The resigned legislators were all returned to LegCo. The voter turnout rate was only 17.1 per cent, ${ }^{8}$ but the CP and LSD claimed success and pointed to the fact that half a million voters (ie 85 per cent of those who voted) had voted in support of their platform.

Meanwhile, the DP and its allies in the Alliance for Universal Suffrage formulated various demands and hoped to persuade the HKSAR Government and Beijing to accept them in exchange for their support for the

4 The strategy of pro-democracy legislators' resignation from LegCo to trigger a de facto referendum on democratisation was first announced by the CP on 6 Sept 2009.

5 The Alliance (also translated as the "Alliance for Ultimate Universal Suffrage") was formed on 24 Jan 2010. See the Alliance's website www.universalsuffrage.hk, which provides, inter alia, the text of its "Proposal on the Road Map to Universal Suffrage" (dated 29 Mar 2010), http://www. universalsuffrage.hk/?p=25\&lang=en (last visited 22 July 2010).

6 On 8 July 2010, the Democratic Party published its report (in Chinese) on the history of its negotiations with the HKSAR Government and Beijing on political reform in 2010. See http://www.dphk.org/wp-content/uploads/2010/07/fullreport_6ppl2.pdf (last visited 22 July 2010): "The Report of the Democratic Party's Six-Person Working Group on Political Reform” (政改六人工作小組報告). The report provides details of the positions taken by the Party before and at different points in time of the negotiations.

7 The statement was made on 15 Jan 2010 and reported in Hong Kong newspapers on 16 Jan.

8 In the LegCo election of 2008, the voter turnout rate was $45.2 \%$. 
Government's constitutional reform proposal. Such demands included, inter alia, Beijing's clarification that the "universal suffrage" promised in the National People's Congress Standing Committee (NPCSC) Decision of $2007^{9}$ is genuine universal suffrage conforming to internationally recognised principles of universality and equality in the electoral system, the nomination "threshold" 10 for the candidates for the election of the Chief Executive (CE) by universal suffrage in 2017 being no higher than the existing nomination threshold for the election of the CE by the Election Committee, the abolition of functional constituencies by the time universal suffrage is introduced for the election of all legislators (in 2010), the adoption of an electoral model for the election of LegCo in 2010, the improvement of the Government's Reform Package to include more democratic elements (eg increasing the newly introduced LegCo seats from 10 to 20; or, instead of elected District Councillors electing 5 additional LegCo seats as proposed in the Reform Package, the additional seats should be elected by universal suffrage (by all voters except those already eligible to vote in existing functional constituencies) upon nomination by elected District Councillors), and the establishment of an institutionalised forum for discussion between the HKSAR Government, Beijing and politicians in Hong Kong on issues of future constitutional development in Hong Kong.

Beijing adopted a strategy of differential treatment of the "moderate" and "radical" camps of the pan-democrats in Hong Kong. Whereas it strongly condemned the "referendum" triggered by the resignation of CP and LSD legislators, it indicated its willingness to engage in a dialogue with the moderates, including the DP, the ADPL and the Alliance for Universal Suffrage. Three widely publicised meetings were held between Mr Li Gang, Vice-Director of the Liaison Office of the Central Government in the HKSAR and representatives of these three groups respectively on the week of 24 May 2010. In particular, the meeting with the DP leaders on 24 May was generally recognised as an important breakthrough or an "ice-breaking voyage" in the relationship between the DP and Beijing: Many of the founders and leaders of the DP had supported the student movement in Beijing in 1989, established the Hong Kong Alliance in Support of Patriotic Democratic Movements in China, and have continued to serve in the leadership of the Alliance since then. The Alliance organised annual demonstrations calling for the rehabilitation of the student movement and annual vigils to mourn

9 See generally Albert H. Y. Chen, "A New Era in Hong Kong's Constitutional History" (2008) 38 HKLJ 1.

10 See Art 45 of the Basic Law of the HKSAR. 
the victims of 4 June 1989. Since 1989, these Hong Kong political activists who subsequently formed the DP were regarded as anti-Beijing, and little official communication existed between them and the Beijing Government.

On 7 June 2010, the HKSAR Government submitted to LegCo the motion for implementing the Reform Package for debate and voting by LegCo before the end of June. The Government made no change to the Reform Package despite the pan-democrats' opposition and their publicly stated position that they would veto the motion. On the same day, Mr Qiao Xiaoyang, Vice-Secretary-General of the NPCSC and Chairman of the Hong Kong Basic Law Committee of the NPCSC, made an important speech in which he attempted to respond to the demands of the DP and its allies. He pointed out that questions such as the nomination "threshold" for candidates for election of the CE by universal suffrage and the fate of functional constituencies as LegCo moves towards election of all legislators by universal suffrage could only be resolved by discussion in future. ${ }^{11}$ In the same speech, Mr Qiao acknowledged (for the first time in a speech by a senior PRC official) ${ }^{12}$ that "universal suffrage" implies universal and equal electoral rights. ${ }^{13}$ But he also pointed out that the international practice is that such rights may be subject to reasonable legal restrictions, and that in the case of Hong Kong, the future electoral system should be consistent with the legal status of the HKSAR and its executive-led political system, should take into account the interests of all social classes in Hong Kong, and should be conducive to the development of Hong Kong's capitalist economy. In his speech, Mr Qiao also commented on the DP's proposal of letting the additional LegCo seats for the District Councils functional constituency be elected by all voters in Hong Kong (other than those who already have the right to vote in an existing functional constituency). He noted that some people had pointed out that this was a form of de facto or quasi

11 In his earlier speech on 14 Apr 2010 (the day on which the HKSAR Government announced the Reform Package), Mr Qiao also referred to the five-step procedure for constitutional reform in Hong Kong stipulated in the NPCSC's Interpretation of 2004 (see generally Albert H. Y. Chen, "The Constitutional Controversy of Spring 2004" (2004) 34 HKLJ 215). According to this procedure, the precise electoral models for election of the CE by universal suffrage in 2017 and the subsequent election of all legislators by universal suffrage can only be settled after the five-step procedure has been initiated shortly before 2017 (in the case of the CE election in 2017) and 2020 (in the case of the LegCo election in 2020) respectively.

12 Months before Mr Qiao's speech, the HKSAR Government had publicly stated that universal suffrage implies the principles of universality and equality, and that the existing mode of elections by functional constituencies of LegCo seats does not satisfy the requirement of universal suffrage. See, eg the speech of Mr Henry Ying-yen Tang, Chief Secretary, in introducing the Reform Package to LegCo on 14 Apr 2010.

$13 \mathrm{Mr}$ Qiao, to the disappointment of the pan-democrats, did not address the question of the right to be a candidate and the right to nominate a candidate. 
direct election and might be inconsistent with the Basic Law and the NPCSC Decision of 2007 (which stipulates that in 2012, the existing 50 per cent:50 per cent ratio of legislators elected by functional constituencies and those elected by direct election in geographical constituencies should remain unchanged).

Given that the Government did not make any concessions by modifying its Reform Package and Mr Qiao's speech failed to satisfy the pandemocrats, the scenario as of 7 June was that the motion for the Reform Package would be vetoed by the pan-democrats - a repetition of what happened in December 2005. ${ }^{14}$ To the surprise of most observers, the situation suddenly changed on 14 June 2010, when Mr Henry Tang, Chief Secretary of the HKSAR Government, met with Mr Albert Chun-yan Ho, DP Chairman, and asked him whether the DP would support the Government's LegCo motion for constitutional reform if the Government were to modify the Reform Package and accept the DP's proposal regarding the five additional District Councils functional constituency seats being elected (after candidates have been jointly nominated by elected District Councillors) by all voters in Hong Kong who do not already have the right to vote in any existing functional constituency ("the DP's District Council electoral proposal"). ${ }^{15}$ The affirmative answer given by $\mathrm{Mr}$ Ho proved to be crucial. ${ }^{16}$

On 17 June, the day of the TV debate between Chief Executive Donald Tsang and CP leader Ms Audrey Eu, Ms Elsie Leung, Vice-Chairman of the Hong Kong Basic Law Committee of the NPCSC, publicly expressed

14 See generally Albert H. Y. Chen, "The Fate of the Constitutional Reform Proposal of October 2005" (2005) 35 HKLJ 537.

15 Approximately 200,000 persons have the right to vote in existing functional constituencies. According to the DP's proposal, more than 3 million registered voters would be enfranchised with regard to the five newly created LegCo functional constituency seats, and all voters in Hong Kong will have two votes - one in a geographical constituency, and one in a functional constituency. The Government's Reform Proposal involves, inter alia, the creation of 10 additional seats in LegCo, 5 of which being elected by universal suffrage in geographical constituencies, and 5 being elected by a new functional constituency consisting of elected District Councillors.

16 Actually, speaking to the media on 13 June 2010, Mr Albert Ho already indicated that if the Government were to accept the DP's District Council electoral proposal, he as DP Chairman would recommend to the DP that the DP should support the modified constitutional reform package. He explained that at the beginning of the negotiations, it was not practicable to put forward this proposal as the Party's only single demand, and other demands were therefore put forward together with it. See "Albert Ho: I would support the political reform if the District Council direct election proposal is accepted” (何俊仁: 區會直選方案獲接納願挺政改), Hong Kong Economic Journal (信報財經新聞), 14 June 2010, p 10. It has also been reported that when the DP leaders met with Mr Li Gang on 24 May, the District Council electoral proposal was particularly emphasised, although other demands were also put forward: see "Democratic Party: We will veto the political reform package if it is not changed” (民主黨: 政改不 加碼即否决), “Five conditions set” (列五大條件), Ming Pao (明報), 25 May 2010, p A2. 
support for the DP's District Council electoral proposal. ${ }^{17}$ In the next few days, there were various signs that this proposal had received the blessings of the HKSAR Government as well as Beijing. On 21 June, Chief Executive Donald Tsang formally announced the Government's acceptance of the proposal as a modification to its original Reform Package. $\mathrm{Mr}$ Wong Yan-lung, Secretary for Justice, explained that the proposal is not inconsistent with the NPCSC Decision of 2007 regarding the ratio of legislators returned by functional constituencies and those elected by direct elections. ${ }^{18}$

On 23 June, LegCo began its deliberations on the Government's motions for amendment of Annexes I and II to the Basic Law. The motions ${ }^{19}$ themselves did not provide details regarding either the original Reform Package or its modified form after the Government accepted the DP's District Council electoral proposal. The Government pointed out that such details could be and would be worked out at the level of

17 Ms Leung subsequently disclosed that she had written to the Beijing authorities on 1 June 2010 expressing her view that the electoral proposal is not inconsistent with the NPCSC Decision of 2007 and expressing support for the proposal. See her press statement dated 9 July 2010 (in Chinese), http://news.mingpao.com/20100710/gga2a_er.htm (last visited 10 July 2010).

18 See his speech to the press at http://www.info.gov.hk/gia/general/201006/21/P201006210168. htm (last visited 22 July 2010). Mr Wong stressed that according to the proposal, (unlike the case in the existing direct elections by universal suffrage in geographical constituencies) eligible voters (for the five newly created functional constituency seats) exclude those already eligible to vote in existing functional constituencies; candidates (for election in the five newly created functional constituency seats) must themselves be elected District Councillors and must be nominated by elected District Councillors. In my opinion, the issue of whether the proposal is inconsistent with the NPCSC Decision of 2007 may be approached as follows: The NPCSC Decision states that in 2012, the ratio of functionally elected legislators and those "directly elected in districts" should remain unchanged. If the DP's proposal involves the election in an all-Hong Kong constituency (i.e. the whole of Hong Kong as one constituency) of five legislators by proportional representation, then they are not "directly elected in districts". The next question is whether they are functionally elected. This concerns how the concept of functional constituencies should be interpreted. The traditional conception of functional constituencies (as alluded to by Vice-Director Li Gang of the Liaison Office when he spoke to the media on 26 May 2010 - two days after he met with the DP) is that of representation of the interests of a particular trade, occupation, profession or sector. But there is nothing to prevent the Central Government and the HKSAR Government from adopting a more open, flexible and creative interpretation of functional constituencies to allow the following functional constituency of a new type to be created: i.e. a new functional constituency consisting of all HK voters who are not already voters in any existing functional constituency - these HK voters (of this new functional constituency) would vote for five District Councillors to become LegCo members, who are jointly nominated by a certain number of District Councillors. This new functional constituency can be understood as a functional constituency of a residuary category (i.e. consisting of voters who are not already voters in the existing functional constituencies) and of a mixed nature in the sense that it has features pertaining to both the residuary functional constituency mentioned above (ie all members of this residuary functional constituency having the right to vote in it) and the District Councils functional constituency (ie only elected District Councillors may nominate and be candidates in the election). If the matter is viewed in this way, then there is no inconsistency between the DP's proposal and the NPCSC Decision.

19 The text of the motions was not new; it had been published together with the original Reform Package. 
local legislation instead of in the amended Annexes to the Basic Law. At the LegCo meeting, the pan-democrats (including the DP) voted in support of a motion to postpone dealing with the Government's motions on the ground that the Government had announced a major revision to the Reform Package only two days ago, and more time should be allowed for public discussion. The pan-democrats' motion to postpone the matter was however defeated when voted on by the separate voting mechanism ${ }^{20}$ (the majority of the legislators elected from functional constituencies opposed the motion). LegCo then proceeded to debate and vote on the Government's motions for amendment of Annexes I and II of the Basic Law. The motion for amendment of Annex I (regarding the electoral model for the CE in 2012) was passed by 46 to 13 votes on 24 June, and that for amendment of Annex II (regarding the electoral model for LegCo in 2012) passed by 46 to 12 votes on 25 June. These were the first amendments to the Basic Law enacted since the Basic Law came into effect in 1997. A major breakthrough in Hong Kong's constitutional reform was thus achieved.

The pan-democrats were bitterly split on the DP's District Council electoral proposal and on the DP's vote in support of the Government's motions to amend Annexes I and II of the Basic Law. The CP, LSD and four other pan-democrats opposed the DP's stance and voted against the Government's motions. Two of the nine DP legislators also opposed the DP's position, and one of the two resigned from the DP in order to vote against the Government's motions. The DP leadership and its supporters justified acceptance of the Government's modified Reform Package by highlighting the progress in terms of democracy it achieved - 10 more seats would be added to LegCo in 2012, with 5 elected by universal suffrage and the other 5 elected by "quasi-universal suffrage", with all voters having two votes (instead of the existing system of 200,000 voters having two votes and 3 million having only one). They also argued that the passage of the modified Reform Package would pave the way for, and would in any event not be detrimental to, the eventual election of the CE and all legislators by universal suffrage. They pointed out that although the five newly created "functional constituency" seats would be filled by elected District Councillors nominated by fellow District Councillors, their direct election by the people of Hong Kong would mean that they would be accountable to the people of Hong Kong instead of to narrow social sectors represented by existing functional constituencies. Opponents of the Government's modified Reform Package argued that it

20 See s II (on the "procedures for voting on bills and motions in LegCo") of Annex II to the Basic Law. 
did nothing to pave the way for the abolition of functional constituencies, and could not be considered progressive. They questioned whether acceptance of the package would only weaken the popular movement to strive for full democratisation in Hong Kong. They also pointed out that questions of the road map to and electoral models for eventual universal suffrage remain unresolved. Some of them even accused the DP of betraying the cause of democracy.

Given that as a matter of political reality, the only alternative to acceptance of the Government's modified Reform Package was vetoing it (as the pan-democrats vetoed the 2005 reform package) and having another period of stagnation in Hong Kong's political development until at least 2016 (the time of the next LegCo election following the 2012 election covered by the Reform Package), the passage by the required two-thirds majority in LegCo of the resolutions for amendment of Annexes I and II should be welcomed. Some opponents of the modified Reform Package have expressed the concern that the Package, in creating five more functional constituency seats, would only perpetuate an unjust system and would be counterproductive in terms of the move towards universal suffrage. They also questioned whether the model (adopted in the modified Reform Package) of members of a functional constituency nominating their members for election by the populace may become in future a model for reforming and thus perpetuating other functional constituencies, thus denying genuine universal suffrage. These are, however, questions for the future on which new political battles will be fought. The DP and other pan-democrats who supported the modified Reform Package have made it clear that they will continue to fight in future for genuine universal suffrage and the abolition of functional constituencies. There is no conflict between accepting the modified Reform Package for 2012 and continuing this fight in future. As for the modified Reform Package itself, it should be recognised that although it is far from perfect, it is more democratic than the existing political system of Hong Kong. The creation in 2012 of additional functional constituency seats in LegCo at the same time as creating additional seats elected by universal suffrage is unavoidable given the constraints imposed by the NPCSC Decision of 2007. But in accordance with the DP's District Council electoral proposal, major political parties, which will be able to win significant numbers of elected District Council seats, will be able to nominate their District Councillors for election by the populace. Ordinary people in Hong Kong will therefore be able to vote for political parties of their choice, not only in the five newly created seats elected directly by universal suffrage, but also in the other five newly created seats of the District Councils functional constituency. The percentage of LegCo seats elected by 
universal suffrage or quasi-universal suffrage (in the case of the District Councils constituency) will thus increase from 50 per cent (in the existing system) to 57 per cent. It cannot be denied that this is a step forward in terms of the democratisation of the HKSAR.

Politics is, in the final analysis, the art of the possible. Since the HKSAR Government put forward the Reform Package in April 2010 which was met by the pan-democrats' opposition, it seemed that the scenario of the pan-democrats vetoing the Government's constitutional reform proposal in December 2005 was likely to repeat itself. Breaking the deadlock was no easy task. This time the "moderate" democrats adopted the innovative strategy of seeking to establish a dialogue with Beijing. In agreeing to meet with them, Beijing made a major policy shift with regard to its relationship with the pan-democrats in Hong Kong, who had for a long time been viewed as anti-Beijing and opposing whatever Beijing said.

Yet, when the DP first met with Mr Li Gang of the Liaison Office on 24 May 2010, their positions seemed to be poles apart. For example, the DP sought assurance from Beijing that there would in 2017 and 2020 be genuine universal suffrage for the election of the CE and all legislators respectively, in the sense of a low nomination "threshold" for candidates for the CE election and the abolition of all functional constituencies. They also demanded an undertaking from Beijing that the proportion of seats directly elected by universal suffrage would be increased in the LegCo of 2016, and the separate voting mechanism should be abolished at that time. ${ }^{21}$ From Beijing's point of view, questions of what precise electoral models will be adopted in 2016, 2017 and 2010 can only be settled in accordance with the five-step procedure stipulated in the NPCSC Interpretation of $2004 .^{22}$ The five-step procedure may only be initiated near the time of the relevant elections. Apart from this legal consideration, there is also the political reality that in order to settle these questions, discussion in Hong Kong among various political forces and in civil society would be necessary. Such discussion is expected to be lengthy and can take place only in future, after the Reform Package for 2012 has been dealt with.

Another principal demand put forward by the DP at its meeting with $\mathrm{Mr} \mathrm{Li}$ was the DP's District Council electoral proposal. Mr Li questioned whether the proposal was consistent with the NPCSC Decision of 2007 regarding the ratio of functionally elected and directly elected legislators 
in 2012. ${ }^{23}$ In my view, there was indeed a genuine legal question regarding the compatibility of the proposal with the NPCSC Decision. ${ }^{24}$ The proposal was, as acknowledged subsequently by leading members of the $\mathrm{DP}$, a form of de facto or quasi direct election. It was most probably outside the contemplation of the NPCSC when making the Decision of 2007 that "election by functional constituencies" could mean the kind of election in the DP's District Council electoral proposal.

It may thus be seen that the ultimate passage of the Government's Reform Package as modified by the DP's proposal was the result of a compromise in which both Beijing and the HKSAR Government on the one hand and the DP made major concessions. It was a classic instance of bargaining and give-and-take in order to make a deal. Both sides would like to see Hong Kong go one step forward in its constitutional reform and democratisation and therefore had the incentive to engage and cooperate with each other. The DP ultimately recognised that for both legal and political reasons, it was impossible to extract from Beijing any meaningful undertakings regarding the precise electoral models for the CE and LegCo after 2012. Thus it was more viable to focus on how the Reform Package for 2012 could be improved in terms of its democratic elements. The HKSAR Government had a strong incentive in securing the passage of the constitutional reform proposal, as its defeat would probably aggravate the lack of popularity and governance crisis which the Government already faced. Beijing probably understood the desperate need to bolster the authority of the HKSAR Government by securing the passage of the constitutional reform proposal. Having initiated the dialogue with the "moderate" democrats, it probably also understood

23 See the DP Report mentioned in $n 6$ above, para 12. The Report disclosed that when DP leaders met with Chief Executive Donald Tsang on 7 June 2010, Mr Tsang told them that he had recommended the DP's District Council electoral proposal to the Beijing authorities three times but without success (see p 27 of the Report). DP Chairman Mr Albert Ho also disclosed that he had met with Mr Tsang several times to discuss the Government's political reform package, and Tsang told him every time that the DP's proposal was contrary to the NPCSC Decision: see “Democratic Party praises Elsie Leung for her contribution to the political reform” (民主黨讚 梁愛詩政改功臣), Ming Pao (明報), 9 July 2010, p A6.

24 In an interview with Ta Kung Pao (大公報) published on 10 June 2010 (p A6) (“Albert Chen: The Opposition's proposal is difficult to implement” (陳弘毅: 反對派方案難實現), I expressed the view that the proposal would probably be considered inconsistent with the NPCSC Decision, as the proposed mode of election was much closer to direct elections than to functional constituency elections. That view was based on the traditional understanding of functional constituencies as being for the purpose of the representation of the interests of a particular trade, occupation, profession, or sector, and the traditional principle that the LegCo member(s) elected by a functional constituency (such as the District Councils functional constituency established since 1999) should be nominated and elected by members of that functional constituency (and not elected by persons outside that functional constituency). For legal aspects of functional constituencies, see, eg the recent case of Chan Yu Nam $v$ Secretary for Justice [2010] 1 HKC 493. For further discussion, see n 18 above. 
that the failure of the dialogue (in achieving anything positive in terms of constitutional reform) would lead to the "moderate" democrats being sidelined and the "radical" democrats - those who engineered the "referendum" which had upset Beijing so much - taking over leadership of the pro-democracy forces in Hong Kong. Thus Beijing ultimately chose to adopt a flexible and creative interpretation of the NPCSC Decision of 2007 (instead of one sticking to its original intention) in giving its blessings to the HKSAR Government's Reform Package as modified by the DP's proposal.

The DP was vehemently attacked by some radical democrats, particularly those in the LSD, for supporting the modified Reform Package. The developments of June 2010 are expected to change significantly the political landscape of Hong Kong. As suggested by a recent survey, ${ }^{25}$ a reshuffling of voters' allegiance is under way. The DP has lost the support of some of its previous voters, but has gained the support of some others who previously voted for other pro-democracy parties or for pro-establishment parties. Corresponding changes in voters' allegiance have been detected with regard to other political parties in Hong Kong. It is possible that the traditional landscape of pro-establishment forces versus pro-democracy forces (gaining 40 per cent and 60 per cent of the popular votes respectively ${ }^{26}$ will give way to a threefold division of pro-establishment forces, the "moderate" democrats (led by the DP) and the "radical" democrats (led by the CP and LSD).

The process of the constitutional reform of 2010 underscores the increasing involvement of Beijing in Hong Kong politics. However, a distinction should be drawn here between "ordinary politics" and "constitutional politics". In the case of the former, Beijing has so far respected the autonomy of the HKSAR Government in decision-making on social, economic and other policies in Hong Kong's domestic affairs in accordance with the Basic Law. But as far as "constitutional politics" is concerned, the NPCSC Interpretation of 2004 and the five-step procedure it specified for constitutional reform ${ }^{27}$ inevitably result in Beijing's involvement in decision-making on constitutional change in Hong Kong. The autonomy which the Basic Law confers on the HKSAR Government is autonomy to govern Hong Kong in accordance with the political system specified in the Basic Law. But changes to the political system itself are not entirely within Hong Kong's autonomy; the precise roles of the

25 "Support for the Democratic Party remains unchanged, the Civic Party gains more support" (民主黨支持度不變，公民黨支持度勁升), Ming Pao (明報), 28 June 2010 .

26 See generally Albert H. Y. Chen, "The Basic Law and the Development of the Political System in Hong Kong” (2007) 15 Asia Pacific Law Review 19.

27 See n 11 above. 
HKSAR Government, the Hong Kong LegCo and Beijing in the process of constitutional reform are specified in the Basic Law and the NPCSC Interpretation of 2004. In the particular case of the constitutional reform of 2010, it was logical for the moderate democrats in Hong Kong to discuss with Beijing matters such as the road map and models for universal suffrage after 2012, as the HKSAR Government had made it clear that it had not been authorised to deal with these matters. ${ }^{28}$ Similarly, the crucial question of whether the DP's District Council electoral proposal was inconsistent with the NPCSC Decision of 2007 was a question which only Beijing could conclusively determine.

The momentous events of June 2010 marked not only a breakthrough in constitutional reform in Hong Kong, but also a breakthrough in the relationship between Beijing and the pro-democracy forces in Hong Kong. Since 1989, the poor relationship and lack of trust between the two sides has been, in this author's opinion, the biggest single stumbling block to Hong Kong's democratisation..$^{29}$ But now, in achieving the constitutional reform of June 2010, Beijing and the moderate wing of the pro-democracy forces in Hong Kong led by the DP have engaged in a dialogue and a process of give-and-take which, coupled with the positive intermediary role played by the HKSAR Government, have proved to be useful and constructive. The future democratisation of the HKSAR depends not only on the existence of a HKSAR Government with prodemocracy inclinations, but also on further interaction and cooperation between the moderate and pragmatic elements in both the Beijing Government and pro-democracy forces in Hong Kong. For this, a good foundation has been laid, a useful precedent established, and a minimum amount of mutual trust and good will secured, by the "miracle" 30 of the constitutional reform of June 2010.

28 See paras $1.28-1.29$ of the Consultation Document referred to in the first paragraph of this article, and paras 5.05-5.06 of the Package of Proposals referred to in the second paragraph of this article.

29 See the work cited in note 26 above.

30 It was widely believed in early June that unless a "miracle" happened, the Government's Reform Package would be vetoed by LegCo in June 2010. 